\title{
The Use of Hydrotropic Solutions for Counter-Current Separations
}

\section{Journal Article}

Author(s):

Winistorfer, Peggy; Kováts, E. Sz.

Publication date:

1967

Permanent link:

https://doi.org/10.3929/ethz-b-000422791

Rights / license:

In Copyright - Non-Commercial Use Permitted

Originally published in:

Journal of Chromatographic Science 5(7), https://doi.org/10.1093/chromsci/5.7.362 


\title{
The Use of Hydrotropic Solutions for Counter-Current Separations
}

\author{
by Peggy Winistorfer and E. sz. Kováts, Swiss Federal Institute of Technology, Department of Industrial \\ and Engineering Chemistry, Zurich, Switzerland
}

The selective dissolving properties of aqueous solutions of hydrotropically active salts* suggest their application as one of the phases in counter-current distribution. However, since hydrotropic activity parallels surface activity (1), such solutions emulsify on shaking with a second solvent; therefore, their use in classical counter-current distribution has been severely limited. Recently, a new variant of an apparatus was realised ( 2 and 3 ) following the original proposal of Signer et al. (4) in which shaking the phases is avoided. Such an apparatus has not yet been described in full detail $\uparrow$. In the present paper, the principle of this method will be explained together with an apparatus of our own construction.

A glass tube is separated into cells (see Figure 1) by the insertion of Teflon disks pierced by a small hole through the center. The more dense solvent which serves as the stationary phase is filled into the cells, its final level being lower than the central hole. The less dense solvent is pumped continuously into the first cell, filling it up to the central hole (the direction of flow is indicated by an arrow in Figure 1), and then passes through the hole to the second cell, to the third cell, etc. Equilibration of the two phases is effected within each cell by rotating the glass tube about its central axis. This rotational movement mixes the two phases and continuously renews their contact surface, leading to equilibration times comparable to those obtained by shaking but without causing foaming. The upper phase is prevented from flowing from one cell to the next without effective mixing by the insertion of smoothly curved stainless steel plates; these also add to the efficiency of the equilibration by longitudinal mixing. Figure 2 shows the whole assembly, the operation of which is described in detail in the experimental part. Essentially, the eluent is pumped through a series of rotating tubes which are parted into cells (in this case, 8 tubes containing 650 cells).

For the application of solutions of hydrotropically active salts in counter-current distribution, a thorough knowledge of their dissolving properties against different classes of substances would be desirable. In the first treatment of hydrotropy, Neuberg (6) investigated the hydrotropic activity of several different salts on a variety of substances by looking at the saturation concentrations. This work only gives information about the solubility of pure substances, thus taking the pure substance as standard state. More recently, Rath, Rau, and Wagner (1 and 7) investigated the dissolving power of many salts but on only one substance.

We have chosen as standard state the ideal diluted solution in a pure one-component non-polar system [non-polarity is defined as a nonpolar substance being only a pure paraffin or mixture of paraffins, $\mathrm{C}_{\mathrm{n}} \mathrm{H}_{2 \mathrm{n}+2}$ (8 and 9) ]. By equilibrating solutions of given substances in n-heptane with solutions of hydrotropically active salts, the partition coefficient clearly defines the chemical potential of the substance in the salt-solution with respect to the standard state in $\mathbf{n}$-heptane. In

*In the literature the terms "hydrotropes" and "hydrotropic substances" are used. The definition of a "hydrotrope" should then be: "a substance which changes the solvent properties of water," implying obviously all water soluble substances. We propose to drop these terms and to speak of the "hydrotropic activity" of a substance and of "hydrotropy" for the effect.

†Private communication from Prof. Dr. R. Signer: The apparatus used for separations in ref. (2) and (3) will be described in a forthcoming paper (5). 
this way one can even examine substances which are completely miscible with both solvents.

It has been suggested that hydrotropic action arises mainly through interactions of polar parts of the solute with the organic ion of the salt (1 and 7 ). For this reason two neutral salts were selected, one having a negatively-charged organic ion - potassium-1-octylsulfonate, and the other having a positivelycharged ion - trimethyl-1-octylammoniumbromide. The organic part of each salt contains the same, non-polar octyl residue.

Figure 3 shows the logarithms of the partition coefficients $K_{c}$ plotted against the percentage concentration (in $\mathrm{g} / 100 \mathrm{ml}$ ) of the two salts, where $K_{c}$ is defined in equation 1 .

$$
\begin{gathered}
\mathbf{K}_{\mathrm{v}}= \\
\text { conc. of the substance } \\
\text { in heptane }\left(\mathrm{g} \cdot \mathrm{cm}^{-3}\right) \\
\hline \text { conc. of the substance } \\
\text { in the salt sol. }\left(\mathrm{g} \cdot \mathrm{cm}^{-3}\right)
\end{gathered}
$$

The same results are shown in Figure 4 but are expressed as $K_{x}$ against molality, where $K_{x}$ is defined in equation 2

$$
\begin{aligned}
& \mathbf{K}_{\mathbf{x}}= \\
& \text { mole fraction of the substance } \\
& \text { in heptane } \\
& \begin{array}{c}
\text { mole fraction of the substance } \\
\text { in the salt sol. }
\end{array}
\end{aligned}
$$

Eq. 2

Neither presentation suggests a
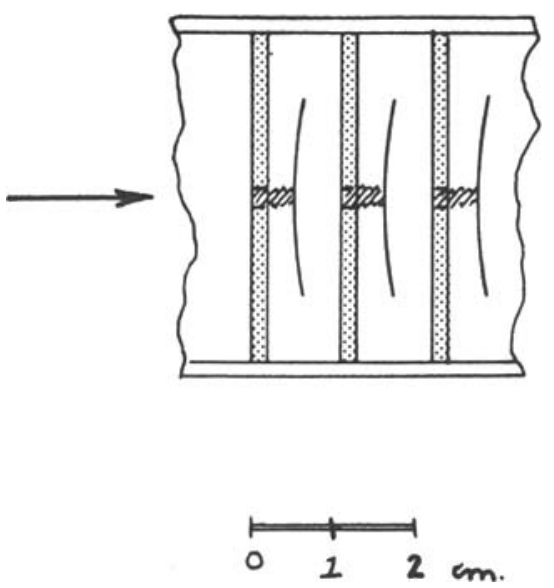

Figure 1. Sectional view of glass counter-current distribution tube showing individual cells. simple interpretation. At low salt concentrations the partition coefficients are more or less constant. For potassium-1-octylsulfonate at about $3 \%$ concentration and for trimethyl1-octylammoniumbromide at $4 \%$ concentration, there is an apparent discontinuity in the shape of the curves. A hydrotropic action of the salts begins actually only at higher concentrations. A possible explanation is that initially the very ordered structure of water is broken down.

In the two figures ( 3 and 4 ) the numbered curves belong to the homologuous series of primary alcohols (2:ethanol, 3:propanol, etc., up to 12:dodecanol). The alcohols have lower partition coefficients in

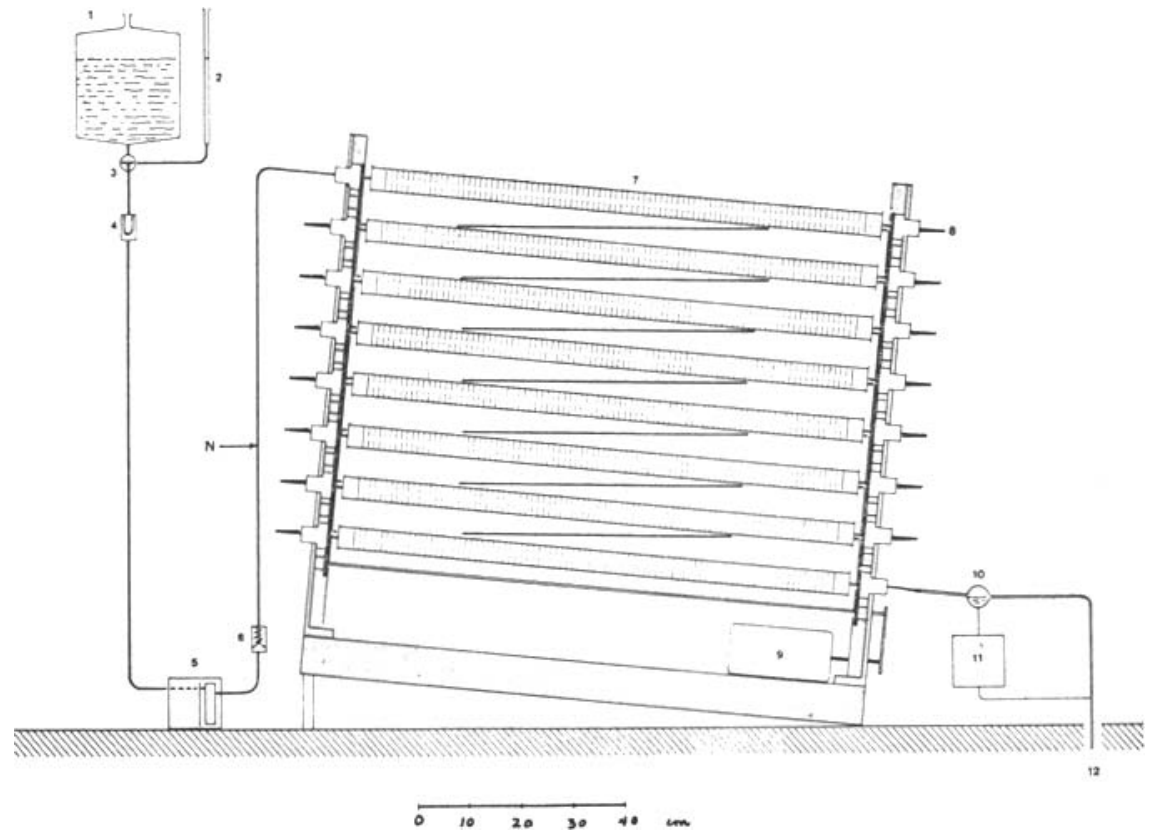

Figure 2. Counter-current distribution apparatus showing rotating tube assembly and feed system.
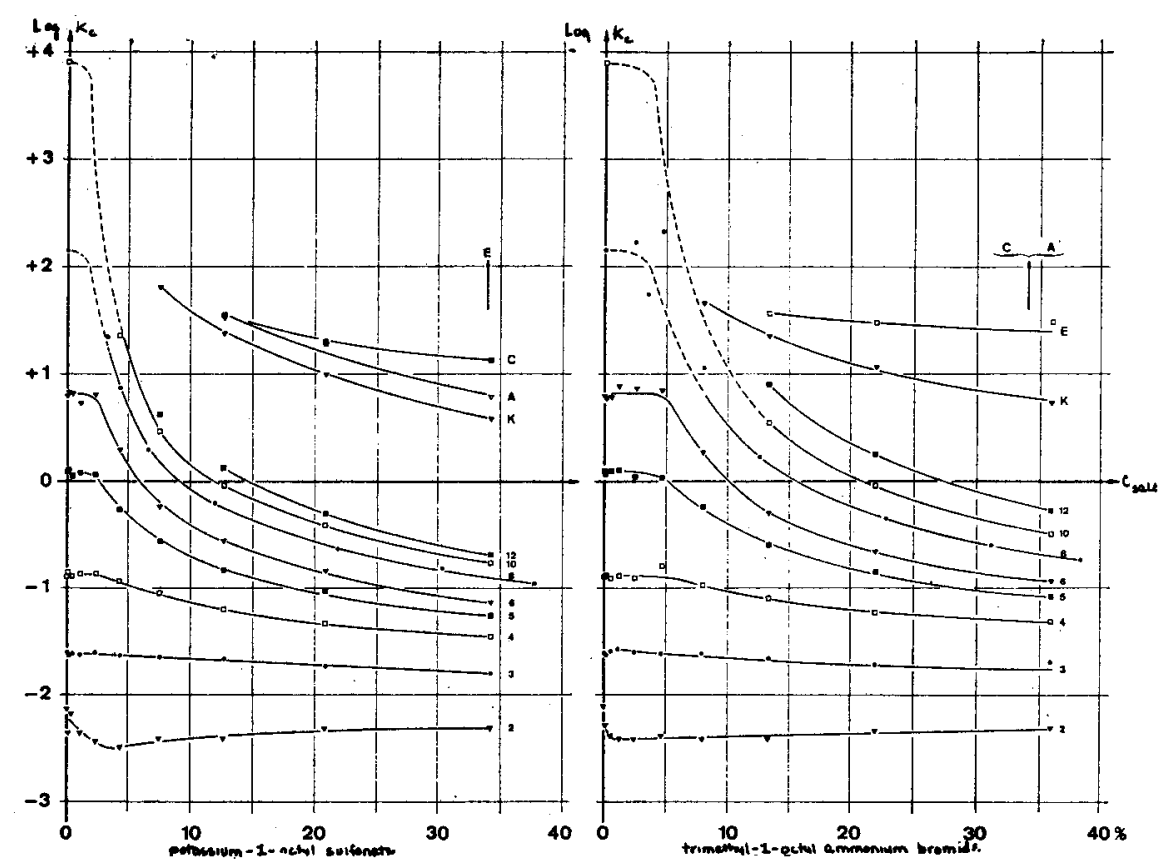

Figure 3. Partition coefficients as a function of percentage composition. 
the solutions of potassium-1-octylsulfonate compared with those of trimethyl-1-octylammoniumbromide. This supports the suggestion of Rath, et al. (7) that in the case of alcohols, one of the main solubilising effects is through hydrogenbonding to the negatively-charged organic ion (in our case, of the 1octylsulfonate ion).

Figure 5 shows the logarithms of $\mathrm{K}_{\mathrm{x}}$ plotted against the carbon-numbers of the alcohols. This plot is linear for the distribution between heptane and pure water. However, in the case of the distribution between heptane and salt solutions, the lines are curved for the lower alcohols tending to linearity for the higher members, with decreasing slope for increasing concentration of the salt.

To detect further differences between the action of the two salts, four additional compounds of distinctly different types were investigated. These are indicated by capital letters in Figures 3 and 4 (A: 1-octylacetate, C: 1-chlorooctane, $\mathrm{E}$ : dipentylether, $\mathrm{K}$ : nonanone(2)). The results for these compounds are difficult to rationalise in any simple scheme. For example, the ketone $(\mathrm{K})$ has a relatively low partition coefficient in both salt solutions. The ether (E) has a preferential solubility in the cationic solvent. Thus, simple arguments might suggest that the acetate (A) which contains both ether and ketone functions should preferentially dissolve in the solutions of trimethyl-1-octylammoniumbromide. However, the contrary is the case.

The results of the present investigation show that the mechanism of hydrotropic action requires much more thorough examination. However, they also show that such solutions are capable of being used as stationary phases for counter-current distribution. The order of the elution would be non-polar substances and substances of low polarity (hydrocarbons), followed by more polar compounds (ethers, esters, aldehydes, ketones, etc.), and finally alcohols. In a homologous series the higher members are eluted first. Preliminary attempts to achieve separations using a solution of potassium-1-octylsulfonate as stationary phase in our countercurrent apparatus are promising.

\section{Experimental}

\section{Materials}

Potassium-1-octylsulfonate was synthesised by the method of Backer (10). Octyl bromide (257 $\mathrm{g}, 1.33$ mole) was heated with an aqueous solution of sodium sulfite (193 $\mathrm{g}$ sodium sulfite, 1.54 mole in $750 \mathrm{ml}$ water) in a copper auto- clave at $170^{\circ} \mathrm{C}$ for $14 \mathrm{hrs}$. To the resulting hot reaction mixture, sodium chloride $(200 \mathrm{~g})$ was added. By cooling the solution the sulfonate could be obtained as a wet crust. The product was freed from water by pressing in a cloth, and the air-dried product was crystallised from absolute ethanol.

An aqueous solution of the sodium sulfonate was filtered onto
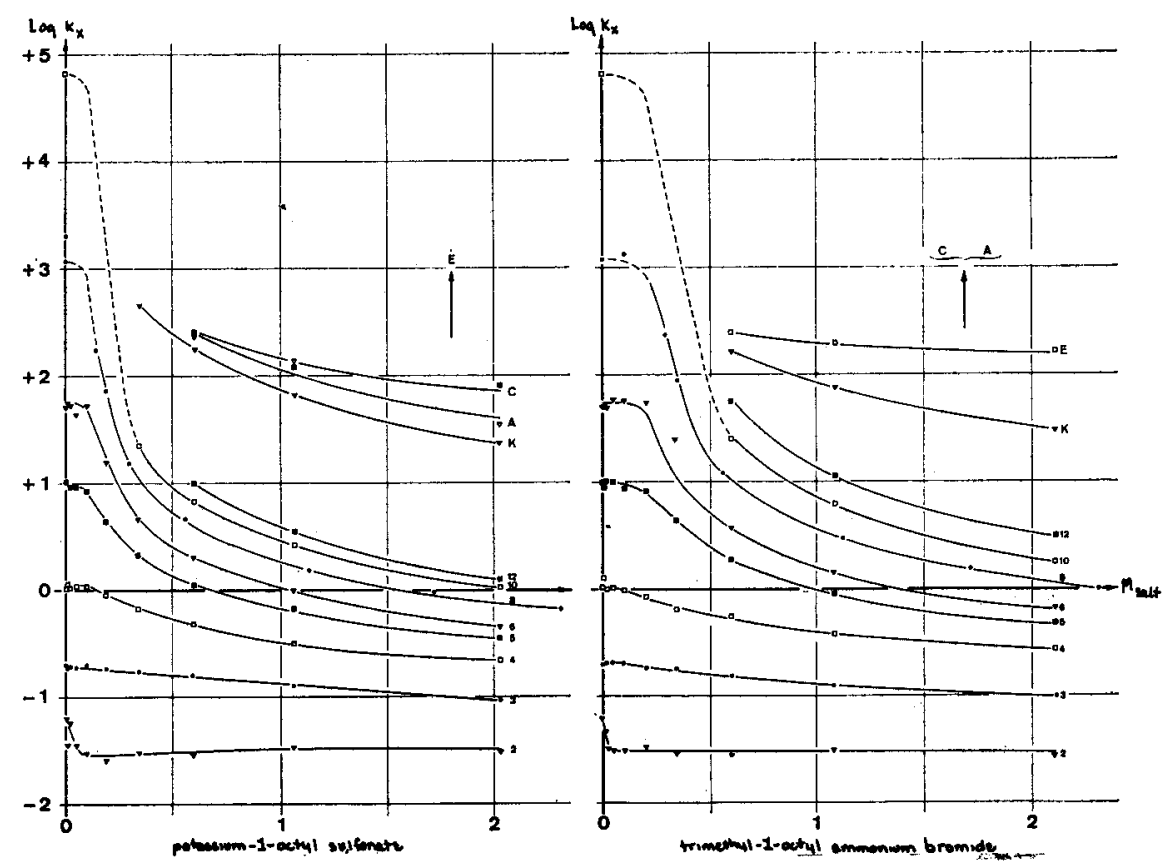

Figure 4. Partition coefficients as a function of molality.
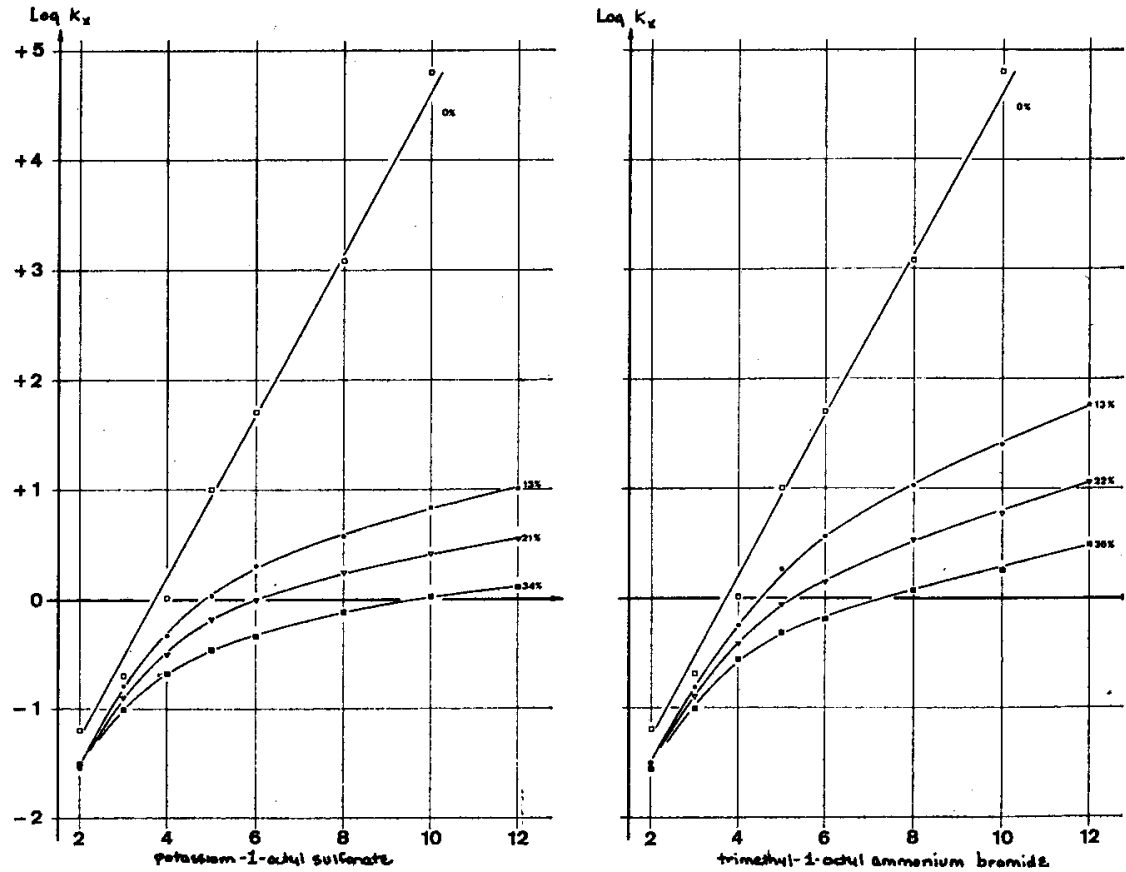

Figure 5. Partition coefficients as a function of the alcohol carbon number. 
an ion exchange column (2000 g Dowex $50 \mathrm{~W}, 20-50$ mesh, prepared as potassium salt). The resulting solution of the potassium sulfonate was evaporated to dryness and the solid product recrystallised from ethanol giving $227 \mathrm{~g}(75 \%)$ potassium-1-octylsulfonate as white crystals.

$\begin{array}{lcccc} & \text { C } & \text { H } & \text { K } & \\ \text { calc } & 41.35 & 7.38 & 16.83 & \% \\ \text { found } & 41.26 & 7.18 & 16.85 & \%\end{array}$

Trimethyl-1-octylammoniumbromide: Octyl bromide (485 g, 2.51 mole) was mixed with trimethylamine (150 g, 2.54 mole) in a pressure flask and was allowed to stand for $72 \mathrm{hrs}$. at room temperature. The crude crystalline product was recrystallised from acetone giving $393 \mathrm{~g}(62 \%)$ trimethyl-1-octylammoniumbromide (m.p. $221 / 2^{\circ} \mathrm{C}$ ).

$$
\mathrm{C} \quad \mathrm{H} \quad \mathrm{N} \quad \mathrm{Br}
$$

calc. $\quad \begin{array}{lllll}52.38 & 10.39 & 5.55 & 31.68 \%\end{array}$ found $\quad 52.24 \quad 10.45 \quad 5.70 \quad 31.51 \%$

Properties of the aqueous solutions of the two salts

Solubility of potassium-1-octylsulfonate: Saturated solutions of this salt were gelatinous and a quantitative value of the saturation concentration could not be obtained. The solubility of the salt was certainly over $47 \%$ at $0^{\circ}$ and $22^{\circ} \mathrm{C}$.

Solubility of trimethyl-1-octylammoniumbromide: Nearly saturated solutions of the salt in water were saturated by pressing through a thermostatted column filled with pills of the salt. Five ml. of the eluent was evaporated to dryness and weighed. Table I shows the saturation concentrations and the densities at different temperatures.

Table I. Saturation concentrations and densities of trimethyl-1octylammoniumbromide in water.

\begin{tabular}{|c|c|c|}
\hline $\begin{array}{l}\text { temp. } \\
\left({ }^{\circ} \mathrm{C}\right)\end{array}$ & $\begin{array}{c}\text { solubility } \\
\mathrm{g} / 100 \mathrm{~g} \\
\text { solution) }\end{array}$ & $\begin{array}{l}\text { density } \\
(\text { g.cm-3) }\end{array}$ \\
\hline 0 & 69.5 & 1.0867 \\
\hline 5 & 68.7 & 1.0827 \\
\hline 10 & 70.5 & 1.0827 \\
\hline 15 & 70.7 & 1.0783 \\
\hline 20 & 71.2 & 1.0746 \\
\hline
\end{tabular}

Densities of aqueous solutions of the two salts: The densities of the solutions were determined in a pyknometer. Tables II and III show the experimental results.

Variance analysis of the results shown in Tables II and III resulted by proving the significance of $\mathbf{P}_{\mathrm{C}}, \mathbf{P}_{\mathrm{CC}}, \mathbf{P}_{\mathrm{CCC}}, \mathbf{P}_{\mathrm{T}}, \mathbf{P}_{\mathrm{TT} T}, \mathbf{P}_{\mathrm{C}} \mathbf{P}_{\mathrm{T}}, \mathbf{P}_{\mathrm{C}} \mathbf{P}_{\mathrm{TT}}$ for potassium-1-octylsulfonate and $\mathbf{P}_{\mathrm{C}}, \mathbf{P}_{\mathrm{T}}, \mathbf{P}_{\mathrm{TT}}, \mathbf{P}_{\mathrm{C}} \mathbf{P}_{\mathrm{T}}$ for trimethyl-1octylammoniumbromide at the $95 \%$ significance level ( $\mathbf{P}_{\mathrm{C}}, \mathbf{P}_{\mathrm{CO}}, \mathbf{P}_{\mathrm{CCO}}$ symbolizing the linear, quadratic, cubic, etc., orthogonal polynominals). Regression equations were calculated with the aid of the significant terms. They allow the calculation of the

Table II. Densities of aqueous solutions of potassium-1-octylsulfonate

\begin{tabular}{ccccc}
$\begin{array}{c}\text { concentration } \\
(\mathrm{g} / \mathrm{g})\end{array}$ & 0 & \multicolumn{5}{c}{ temperature $\left({ }^{\circ} \mathrm{C}\right)$} \\
\hline \hline 0 & 0.9999 & 0.9982 & 0.9922 & 0.9832 \\
15 & 1.0426 & 1.0373 & 1.0281 & 1.0179 \\
30 & 1.0731 & 1.0652 & 1.0547 & 1.0432 \\
45 & 1.1121 & 1.1005 & 1.0888 & 1.0760 \\
\hline
\end{tabular}

Table III. Densities of aqueous solutions of trimethyl-1-octylammoniumbromide

\begin{tabular}{ccccc}
$\begin{array}{c}\text { concentration } \\
(\mathrm{g} / \mathrm{g})\end{array}$ & 0 & \multicolumn{4}{c}{ temperature $\left({ }^{\circ} \mathrm{C}\right)$} \\
\hline \hline 0 & 0.9999 & 0.9982 & 40 & 60 \\
16.7 & 1.0199 & 1.0147 & 0.9922 & 0.9827 \\
33.3 & 1.0405 & 1.0327 & 1.0227 & 0.9965 \\
50.0 & 1.0606 & 1.0492 & 1.0404 & 1.0102 \\
\hline
\end{tabular}

Table IV. Concentrations of the aqueous solutions used of potassium-1-octylsulfonate at $20^{\circ} \mathrm{C}$

\begin{tabular}{|c|c|c|c|c|c|c|c|}
\hline$g / g$ & $\mathrm{~g} / \mathrm{cm}^{3}$ & $\mathrm{~cm}^{3} / \mathrm{cm}^{3}$ & $\begin{array}{l}\text { gmol } \\
\text { gmol }\end{array}$ & $\begin{array}{c}\text { gmol } \\
\mathbf{g}\left(\mathrm{H}_{2} \mathrm{O}\right)\end{array}$ & $\begin{array}{c}\mathbf{c m}^{3} \\
\mathbf{c m}^{3}\left(\mathrm{H}_{2} \mathrm{O}\right)\end{array}$ & gmol & $\mathrm{g} / \mathrm{cm}^{3}$ \\
\hline $\begin{array}{c}c^{\prime} \\
100\end{array}$ & $\begin{array}{c}c \\
100\end{array}$ & $\begin{array}{c}\alpha \\
100\end{array}$ & $\begin{array}{c}x \\
100\end{array}$ & $\begin{array}{c}\mathrm{m} \\
1000\end{array}$ & $\begin{array}{c}\beta \\
1000 \\
\end{array}$ & $\mathbf{M}$ & $d_{20}$ \\
\hline 0.0000 & 0.0000 & 0.0000 & 0.0000 & 0.00000 & 0.000 & 18.016 & 0.9982 \\
\hline 0.0953 & 0.0952 & 0.0635 & 0.0073 & 0.00410 & 0.635 & 18.031 & 0.9989 \\
\hline 0.4322 & 0.4322 & 0.292 & 0.0336 & 0.01867 & 2.928 & 18.088 & 1.0001 \\
\hline 1.1201 & 1.1227 & 0.768 & 0.0877 & 0.04874 & 7.739 & 18.204 & 1.0023 \\
\hline 2.317 & 2.330 & 1.627 & 0.1835 & 0.10206 & 16.539 & 18.409 & 1.0060 \\
\hline 3.199 & 3.227 & 2.285 & 0.2555 & 0.14221 & 23.384 & 18.564 & 1.0087 \\
\hline 4.269 & 4.319 & 3.110 & 0.3445 & 0.19189 & 32.098 & 18.755 & 1.0118 \\
\hline 6.493 & 6.609 & 4.904 & 0.5354 & 0.29880 & 51.569 & 19.164 & 1.0178 \\
\hline 7.353 & 7.501 & 5.633 & 0.6115 & 0.34152 & 59.692 & 19.327 & 1.0201 \\
\hline 11.527 & 11.872 & 9.284 & 1.0000 & 0.56065 & 102.341 & 20.160 & 1.0299 \\
\hline 12.184 & 12.567 & 9.877 & 1.0632 & 0.59703 & 109.595 & 20.297 & 1.0314 \\
\hline 19.802 & 20.725 & 17.014 & 1.8782 & 1.06250 & 205.023 & 22.042 & 1.0466 \\
\hline 20.839 & 21.850 & 17.961 & 2.0000 & 1.13279 & 218.932 & 22.304 & 1.0485 \\
\hline 28.517 & 30.216 & 24.928 & 3.0000 & 1.71666 & 332.055 & 24.447 & 1.0626 \\
\hline 32.023 & 34.245 & 28.047 & 3.5234 & 2.02713 & 389.796 & 25.569 & 1.0694 \\
\hline 34.958 & 37.601 & 30.532 & 4.0000 & 2.31278 & 439.512 & 26.591 & 1.0756 \\
\hline
\end{tabular}


density between the experimental limits. The densities as a function of the linear orthogonal polynomials are as follows:

for potassium-1-octylsulfonate:

$\mathrm{d}=1.04677+0.02621 \mathbf{P}_{\mathrm{C}}$

$$
\begin{aligned}
& -0.00070 \mathrm{P}^{2} \mathrm{~d}+0.00304 \mathrm{P}^{3}{ }_{\mathrm{C}} \\
& -0.00899 \mathrm{P}_{\mathrm{T}}-0.00106 \mathrm{P}^{2}{ }_{\mathrm{T}} \\
& -0.00209 \mathrm{P}_{\mathrm{C}} \mathrm{P}_{\mathrm{T}} \\
& +0.00049 \mathrm{P}_{\mathrm{C}} \mathrm{P}^{2}{ }_{\mathrm{T}}
\end{aligned}
$$

Eq. 3

where

$$
\begin{array}{lrrrr}
\mathrm{P}_{\mathrm{c}}= & -1.5 & -0.5 & +0.5 & +1.5 \\
\begin{array}{l}
\mathrm{c}^{\prime}= \\
\%(\mathrm{~g} / \mathrm{g})
\end{array} & 0 & 15 & 30 & 45 \\
\mathrm{P}_{\mathrm{T}}= & -1.5 & -0.5 & +0.5 & +1.5 \\
\begin{array}{l}
\mathrm{T}= \\
\left({ }^{\circ} \mathrm{C}\right)
\end{array} & 0 & 20 & 40 & 60
\end{array}
$$

for trimethyl-1-octylammoniumbromide:

$$
\begin{aligned}
\mathrm{d}= & 1.01996+0.01699 \mathrm{P}_{\mathrm{C}} \\
& -0.00868 \mathrm{P}_{\mathrm{T}}-0.00126 \mathrm{P}_{\mathrm{T}} \\
& -0.00183 \mathrm{P}_{\mathrm{C}} \mathrm{P}_{\mathrm{T}}
\end{aligned}
$$

Eq. 4

where

$P_{0}=\quad-1.5-0.5+0.5+1.5$

$\begin{array}{lllll}\mathrm{c}^{\prime}= & 0 & 16.7 & 33.3 & 50.0\end{array}$

$\%(\mathrm{~g} / \mathrm{g})$

$\mathrm{P}_{\mathrm{T}}=\quad-1.5-0.5+0.5+1.5$

$\begin{array}{lllll}\mathrm{T}= & 0 & 20 & 40 & 60\end{array}$

$\left({ }^{\circ} \mathrm{C}\right)$

\section{Concentration data}

Knowing the density and the molecular weights, the concentration data in different dimensions can be interconverted. Table IV and V show the interconverted data for the solutions used at $20^{\circ} \mathrm{C}$. They were calculated as follows:

$\mathbf{c}^{\prime}\left(\mathbf{g}_{\text {salt }} / \mathbf{g}_{\text {solution }}\right):$ Solutions were prepared by weighing the salt and the water. This concentration is independent of temperature.

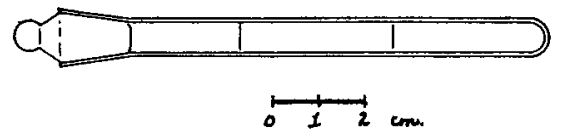

Figure 6. Small stoppered glass tube used for equilibration of $n$-heptane and salt solutions. c $\left(g_{\text {salt }} / \mathbf{c m}^{3}{ }_{\text {solution }}\right): c=c^{\prime} \cdot d_{20}$ Eq. 5 $\alpha\left(\mathrm{cm}^{3}{ }_{\text {salt }} / \mathrm{cm}^{3}{ }_{\text {solution }}\right):$ From the density determinations the specific volume $V=1 / d$ can be calculated. The partial volume of the salt which satisfies (6)

$$
\mathrm{V}=\mathrm{c} \cdot \mathrm{V}_{\mathrm{salt}}+(1-\mathrm{c}) \cdot \mathrm{V}_{\mathrm{H} 2 \mathrm{O}}
$$
Eq. 6

can easily be calculated with the aid of the equation 7

$$
\mathrm{V}_{\mathrm{sa} 1 \mathrm{t}}=\mathrm{V}-\mathbf{c}^{\prime}\left(\partial \mathrm{V} / \partial \mathbf{c}^{\prime}\right)
$$

Eq. 7

\begin{tabular}{|c|c|c|c|c|c|c|c|}
\hline $\begin{array}{c}c^{\prime} \\
100\end{array}$ & $\begin{array}{c}c \\
100\end{array}$ & $\begin{array}{c}\alpha \\
100\end{array}$ & $\begin{array}{c}x \\
100\end{array}$ & $\underset{1000}{m}$ & $\begin{array}{c}\beta \\
1000\end{array}$ & $\mathbf{M}$ & $d_{20}$ \\
\hline 0.0000 & 0.0000 & 0.0000 & 0.0000 & 0.00000 & 0.000 & 18.016 & \\
\hline 0.1034 & 0.1031 & 0.0948 & 0.0074 & 0.00410 & 0.949 & 18.033 & 0.9972 \\
\hline 0.4692 & 0.4681 & 0.431 & 0.0337 & 0.01869 & 4.329 & 18.0 & 0.997 \\
\hline 1.2158 & 1.2139 & 1.116 & 0.0878 & 0.04879 & 11.286 & 18.222 & 998 \\
\hline 2.515 & 2.514 & 2.306 & 0.1839 & 0.10227 & 23.604 & 18.447 & 0.999 \\
\hline 3.501 & 3.504 & 3.210 & 0.2584 & 0.14383 & 33.165 & 18.621 & 1.000 \\
\hline 4.634 & 4.644 & 4.245 & 0.3458 & 0.19263 & 44.332 & 18.826 & 1.0021 \\
\hline 6.801 & 6.831 & 6.223 & 0.5185 & 0.28928 & 66.360 & 19.230 & 1.0044 \\
\hline 7.981 & 8.026 & 7.300 & 0.6156 & 0.34383 & 78.749 & 19.458 & 1.0057 \\
\hline 12.404 & 12.533 & 11.346 & 1.0012 & 0.56136 & 127.981 & 20.361 & 1.010 \\
\hline 13.225 & 13.374 & 12.097 & 1.0768 & 0.60417 & 137.618 & 20.538 & 1.0113 \\
\hline 1.493 & 21.927 & 19.734 & 1.9178 & 1.08530 & 245.858 & 22.508 & 1.020 \\
\hline 2.200 & 22.664 & 20.398 & 1.9972 & 1.13120 & 256.245 & 22.694 & 1.020 \\
\hline 0.192 & & 27.944 & 2.9964 & 1.71455 & 387.809 & 25.035 & 1.029 \\
\hline 34.759 & 35.955 & 32.323 & 3.6656 & 2.11208 & 477.607 & 26.602 & 1.0344 \\
\hline 36.799 & 38.146 & 34.331 & 3.9925 & 2.30821 & 522.789 & 27.368 & 1.0366 \\
\hline
\end{tabular}

The volume fraction is then given by

$$
\alpha=\mathbf{c} \cdot \mathbf{V}_{\text {salt }}
$$

Eq. 8

x (g mole salt $_{\text {s }} / g$ mole $\left._{\text {solution }}\right)$ : For the mixture of the components a mean molecular weight can be defined which in our case is as follows:

$$
\frac{1}{M_{\text {solution }}}=\frac{c_{\text {salt }}^{\prime}}{M_{\text {salt }}}+\frac{1-\mathbf{c}_{\text {salt }}^{\prime}}{M_{\text {H2o }}}
$$

Eq. 9

Table V. Concentrations of the aqueous solutions used of trimethyl-1-octylammoniumbromide at $20^{\circ} \mathrm{C}$

$\mathrm{g} / \mathrm{g} \mathrm{g} / \mathrm{cm}^{3} \mathrm{~cm}^{3} / \mathrm{cm}^{3} \mathrm{gmol} \mathrm{gmol} \quad \mathrm{cm}^{3} \mathrm{gmol} \mathrm{g} / \mathrm{cm}^{3}$

Table IVa. Concentrations of the substances and markers in n-heptane

\begin{tabular}{lcclc} 
substance & \multicolumn{2}{c}{ concentration } & marker & $\begin{array}{c}\text { concentration } \\
\left(\mathrm{g} / 100_{\text {sol }}\right)\end{array}$ \\
\hline \hline ethanol & 4.622 & 1.0 & hexane & 0.470 \\
propanol-(1) & 1.207 & 0.2 & hexane & 0.492 \\
butanol-(1) & 1.479 & 0.2 & undecane & 0.490 \\
pentanol-(1) & 1.770 & 0.2 & decane & 0.490 \\
hexanol-(1) & 2.040 & 0.2 & undecane & 0.488 \\
octanol-(1) & 2.603 & 0.2 & decane & 1.452 \\
decanol-(1) & 3.160 & 0.2 & undecane & 0.962 \\
dodecanol-(1) & 3.720 & 0.2 & tridecane & 0.956 \\
dipentylether & 3.171 & 0.2 & undecane & 1.439 \\
1-chlorooctane & 2.980 & 0.2 & undecane & 1.449 \\
1-acetoxyoctane & 3.458 & 0.2 & dodecane & 1.441 \\
nonanone-(2) & 2.852 & 0.2 & undecane & 1.448 \\
\hline
\end{tabular}


where M's represent molecular weights. The mean molecular weight allows then calculation of the " $g$ moles of the solution."

$$
\begin{array}{r}
\eta_{\text {solution }}=\eta_{\text {salt }}+\eta_{\text {HeO }}= \\
\frac{\mathbf{w}_{\text {solution }}}{\mathbf{M}_{\text {solution }}}
\end{array}
$$

where $\mathrm{w}$ is the weight. The mean molecular weights are given in Table IV and V. Knowing the mean molecular weight, the mole fraction of the solution is given by (11)

$$
\mathbf{x}_{\text {salt }}=\frac{\mathbf{c}^{\prime} \cdot \mathbf{M}_{\text {soluiton }}}{\mathbf{M}_{\text {salt }}}
$$

$\mathrm{m}\left(\mathrm{g} \mathrm{mole}_{\mathrm{sa} \mathrm{tt}} / \mathrm{cm}^{3}{ }_{\mathrm{H} 2 \mathrm{O}}\right)$ : The molality of the salt can be calculated as

$$
\mathbf{m}=\mathbf{M}_{\mathrm{sa} 1 \mathrm{t}} \cdot \mathrm{c}^{\prime} /\left(\mathbf{1}-\mathbf{c}^{\prime}\right)
$$

$\beta\left(\mathrm{cm}^{3}{ }_{\mathrm{salt}} / \mathrm{cm}^{3}{ }_{\mathrm{H} 2 \mathrm{O}}\right)$ : The volume ratio is defined by (13)

$$
\beta=\left(\mathrm{cV}_{\mathrm{salt}}\right) /\left[(1-\mathrm{c}) \cdot \mathrm{V}_{\mathrm{H} 2 \mathrm{O}}\right]
$$

and can easily be calculated if the function $\alpha$ is known and is given by

$$
\beta=\alpha /(1-\alpha)
$$

Eq. 14

\section{Determination of the partition coefficients}

Equilibration of the two phases: The substance to be examined was dissolved in the organic phase ( $\mathrm{n}$ heptane). $1 \mathrm{ml}$ of this solution of known concentration was placed in a small glass tube (Figure 6), and $1 \mathrm{ml}$ of the salt solution was added together with a small nickel ball. The tube was closed and fixed on an axis which was moving with a rocking motion with a period of 4 RPM under thermostatted water $\left(20.0^{\circ} \mathrm{C}\right)$. Thus, the two phases passed over each other and in addition were mixed by the falling movement of the nickel ball.

Experiments have shown that the kinetics of the substance transport from one phase to the other had a half-life of about $20 \mathrm{sec}$. For security the two phases were equilibrated for $30 \mathrm{~min}$. Finally, the tube was quickly centrifuged at room temperature, and a small part of the heptane phase was taken for gas chromatographic analysis.
Gas chromatographic analysis: All the substances investigated were chosen to be volatile for rapid concentration determination by gas chromatography. In the hydrotropic solutions used, the n-paraffins were practically insoluble. Experiments with n-decane have shown that the partition coefficient of this substance is certainly higher than 1000 . Thus, these substances can be used as markers, assuming their concentrations are unchanged during the equilibration experiment. Table IVa shows the concentration of substances in $\mathbf{n}$-heptane as well as those of the markers.

The concentration of the substance was taken as low as possible with the exception of the ethanol. In the latter case the partition coefficients were very low, and an analysis was only possible at higher concentrations. Proof will be given that the concentration chosen can be regarded as ideal diluted.

For the evaluation of the chromatograms a correction factor $f(15)$ has been determined with the aid of the prepared solutions, which allows the calculation of the concentration of the substances from the ratio of the peak-areas (substance/marker). This is given from the chromatograms of the prepared solutions:

$$
\mathbf{f}=\frac{A_{\mathrm{s}}}{A_{M}} \cdot \frac{c_{M}}{c_{M}}
$$

Eq. 15

where $A$ is the peak-area in the chromatogram and $c$ the concentration in $\mathrm{g} / \mathrm{cm}^{3}$.

After equilibration, the $n$-heptane phases were again chromatographed and the area-ratio determined giving

$$
\mathrm{c}_{\mathrm{s}, \alpha} \alpha=\left(\mathrm{A}_{\mathrm{s}}^{\prime} / \mathrm{A}_{\mathrm{M}}\right) \cdot \mathrm{c}_{\mathrm{M}} \cdot \mathbf{1 / \mathrm { f }}
$$

the index $\alpha$ referring to the heptane phase.

The concentration $c_{\mathrm{s},} \alpha$ would be the correct concentration for infinitely diluted solutions. For more concentrated solutions the substance transport during equilibration is accompanied by a volume change, $\delta \mathrm{V}$; i.e., the volume of the both phases after equilibration is $V \alpha_{, o}+\delta V$ and $V \beta_{, o}-\delta V$. Supposing that the substance dissolves in both phases without volume con- traction, then $\delta \mathrm{V}$ is given by

$$
\delta \mathrm{V}=\frac{\mathrm{V} \alpha_{, o}}{\mathrm{~d}_{\mathrm{s}}} \cdot\left(\mathrm{c}_{\mathrm{s}, \alpha_{, 0}}-\mathrm{c}_{\mathrm{s}, \alpha}^{*}\right)
$$

where $V \alpha_{, 0}$ is the volume of the heptane phase before equilibration. The corrected concentration is then given by (18)

$$
\mathrm{c}_{\mathrm{s}, \alpha}=\mathrm{c}_{\mathrm{s}, \alpha}, \frac{1}{1-\left(\delta \mathrm{V} / \mathrm{V} \alpha_{, 0}\right)}
$$

The concentration in the salt solution (phase $\beta$ ) was in most cases not determined. It can be calculated if ${ }^{*}{ }_{\mathrm{s},} \alpha$ is known:

$$
\begin{gathered}
\left.\mathbf{c}_{\mathbf{s}, \beta}=\mathbf{c}^{*} \mathbf{S}_{, \alpha, 0}-\mathbf{c}^{*}{ }_{\mathrm{s}, \alpha}\right) \\
\frac{1}{1 / \phi+\left(\delta \mathrm{V} / \mathrm{V} \alpha_{, 0}\right)}
\end{gathered}
$$

where $\phi$ is the phase ratio $(\mathrm{V} \alpha, \mathrm{o} /$ $\left.\mathrm{V} \beta \beta_{0}\right)$

Calculation of the partition coefficients: from the above results the partition coefficients can be calculated as:

$$
\mathbf{K}_{\mathrm{c}}=\mathbf{c}_{\mathrm{s}, \alpha} \alpha \mathbf{c}_{\mathrm{s}, \beta}
$$

Eq. 20

Tables V and VI show the experimentally determined partition coefficients, $K_{c}$, and their logarithms as well as two other partition coefficients $\left(K_{m}\right.$ and $K_{x}$, see below) with their logarithms, which can be calculated from $\mathbf{K}_{c}$ :

a) if the concentration of the substance is given in mass of substance per mass of solution, the partition coefficient $K_{m}$ can be calculated:

$$
\begin{aligned}
\mathbf{K}_{\mathrm{m}}=\mathbf{K}_{\mathrm{c}} \cdot(\mathbf{d} \beta / \mathbf{d} \alpha)= \\
\mathbf{K}_{\mathrm{c}} \cdot \frac{\mathbf{d}_{\text {solution }}}{\mathbf{d}_{\text {heptane }}}
\end{aligned}
$$

for the ideal diluted case.

b) if the concentration of the substance is given in mole fraction or mole $\%$ the partition coefficient changes into:

$$
\mathbf{K}_{\mathbf{x}}=\mathbf{K}_{\mathbf{c}} \cdot \frac{\mathbf{d}_{\text {solution }}}{\mathbf{d}_{\text {heptane }}} \frac{\mathbf{M}_{\text {heptane }}}{\mathbf{M}_{\text {solution }}^{\text {Eq. 22 }}}
$$

Dependence of the partition coefficients on the substance concentration: Tables VII and VIII show the logarithms of the partition coefficients $K_{c}$ at different salt concentrations and with different sub- 
Table V. Partition coefficients between heptane and aqueous solutions of potassium-1-octylsulfonate

\begin{tabular}{|c|c|c|c|c|c|c|c|c|c|c|c|c|}
\hline \multirow[b]{2}{*}{$\mathbf{c}^{\prime}$} & \multirow[b]{2}{*}{$-\log \gamma$} & & \multicolumn{2}{|c|}{ Ethanol } & \multicolumn{2}{|c|}{ Propanol-(1) } & \multicolumn{2}{|c|}{ Butanol-(1) } & \multicolumn{2}{|c|}{ Pentanol-(1) } & \multicolumn{2}{|c|}{ Hexanol-(1) } \\
\hline & & & $\mathbf{K}$ & $\log k$ & $\mathrm{~K}$ & $\log K$ & $\mathbf{K}$ & $\log \mathrm{K}$ & $\mathbf{K}$ & $\log \mathrm{K}$ & $\mathbf{K}$ & $\log K$ \\
\hline 0.0000 & 0.00000 & $\begin{array}{l}\mathbf{K}_{\mathrm{c}} \\
\mathbf{K}_{\mathrm{m}} \\
\mathbf{K}_{\mathbf{x}}\end{array}$ & $\begin{array}{l}0.00773 \\
0.0113 \\
0.0628\end{array}$ & $\begin{array}{l}0.888-3 \\
0.053-2 \\
0.798-2\end{array}$ & $\begin{array}{l}0.0246 \\
0.0345 \\
0.200\end{array}$ & $\begin{array}{l}0.391-2 \\
0.555-2 \\
0.301-1\end{array}$ & $\begin{array}{l}0.127 \\
0.185 \\
1.032\end{array}$ & $\begin{array}{l}0.104-1 \\
0.268-1 \\
0.014\end{array}$ & $\begin{array}{c}1.242 \\
1.814 \\
10.09\end{array}$ & $\begin{array}{l}0.094 \\
0.259 \\
1.004\end{array}$ & $\begin{array}{r}6.12 \\
8.94 \\
49.7\end{array}$ & $\begin{array}{l}0.787 \\
0.951 \\
1.696\end{array}$ \\
\hline 0.0953 & 0.03009 & $\begin{array}{l}\mathbf{K}_{\mathrm{o}} \\
\mathbf{K}_{\mathbf{m}} \\
\mathbf{K}_{\mathbf{x}}\end{array}$ & $\begin{array}{l}0.00437 \\
0.00639 \\
0.0355\end{array}$ & $\begin{array}{l}0.640-3 \\
0.805-3 \\
0.550-2\end{array}$ & $\begin{array}{l}0.0232 \\
0.0339 \\
0.189\end{array}$ & $\begin{array}{l}0.366-2 \\
0.530-2 \\
0.276-1\end{array}$ & $\begin{array}{l}0.141 \\
0.206 \\
1.145\end{array}$ & $\begin{array}{l}0.149-1 \\
0.314-1 \\
0.059\end{array}$ & $\begin{array}{c}1.288 \\
1.881 \\
10.46\end{array}$ & $\begin{array}{l}0.110 \\
0.275 \\
1.020\end{array}$ & $\begin{array}{c}6.77 \\
9.90 \\
55.5\end{array}$ & $\begin{array}{l}0.831 \\
0.996 \\
1.744\end{array}$ \\
\hline 0.4322 & 0.06011 & $\begin{array}{l}\mathbf{K}_{\mathrm{c}} \\
\mathbf{K}_{\mathbf{m}} \\
\mathbf{K}_{\mathbf{x}}\end{array}$ & $\begin{array}{l}0.00668 \\
0.00978 \\
0.0542\end{array}$ & $\begin{array}{l}0.825-3 \\
0.990-3 \\
0.734-2\end{array}$ & $\begin{array}{l}0.0241 \\
0.0353 \\
0.195\end{array}$ & $\begin{array}{l}0.382-2 \\
0.548-2 \\
0.290-1\end{array}$ & $\begin{array}{l}0.129 \\
0.189 \\
1.045\end{array}$ & $\begin{array}{l}0.111-1 \\
0.276-1 \\
0.019\end{array}$ & $\begin{array}{l}1.134 \\
1.659 \\
9.19\end{array}$ & $\begin{array}{l}0.055 \\
0.220 \\
0.963\end{array}$ & $\begin{array}{r}6.57 \\
9.61 \\
53.2\end{array}$ & $\begin{array}{l}0.818 \\
0.983 \\
1.726\end{array}$ \\
\hline 1.1201 & 0.09042 & $\begin{array}{l}\mathbf{K}_{\mathrm{o}} \\
\mathbf{K}_{\mathrm{m}} \\
\mathbf{K}_{\mathbf{x}}\end{array}$ & $\begin{array}{l}0.00437 \\
0.00641 \\
0.0353\end{array}$ & $\begin{array}{l}0.640-3 \\
0.807-3 \\
0.548-2\end{array}$ & $\begin{array}{l}0.0241 \\
0.0353 \\
0.1945\end{array}$ & $\begin{array}{l}0.382-2 \\
0.548-2 \\
0.289-1\end{array}$ & $\begin{array}{l}0.135 \\
0.198 \\
1.089\end{array}$ & $\begin{array}{l}0.131-1 \\
0.297-1 \\
0.037\end{array}$ & $\begin{array}{l}1.212 \\
1.776 \\
9.78\end{array}$ & $\begin{array}{l}0.084 \\
0.250 \\
0.990\end{array}$ & $\begin{array}{r}5.37 \\
7.87 \\
43.4\end{array}$ & $\begin{array}{l}0.730 \\
0.896 \\
1.638\end{array}$ \\
\hline 2.317 & 0.12106 & $\begin{array}{l}\mathbf{K}_{\mathrm{c}} \\
\mathbf{K}_{\mathrm{m}} \\
\mathbf{K}_{\mathbf{x}}\end{array}$ & $\begin{array}{l}0.00367 \\
0.00540 \\
0.0294\end{array}$ & & $\begin{array}{l}0.0250 \\
0.0368 \\
0.200\end{array}$ & & $\begin{array}{l}0.136 \\
0.200 \\
1.088\end{array}$ & $\begin{array}{l}0.134-1 \\
0.301-1 \\
0.037\end{array}$ & $\begin{array}{l}1.161 \\
1.709 \\
9.29\end{array}$ & $\begin{array}{l}0.065 \\
0.233 \\
0.968\end{array}$ & $\begin{array}{c}6.54 \\
9.62 \\
52.3\end{array}$ & $\begin{array}{l}0.816 \\
0.984 \\
1.719\end{array}$ \\
\hline 3.199 & 0.13692 & $\begin{array}{l}\mathbf{K}_{\mathrm{c}} \\
\mathbf{K}_{\mathrm{m}} \\
\mathbf{K}_{\mathrm{x}}\end{array}$ & & & & & & & & & & \\
\hline 4.269 & 0.15231 & $\begin{array}{l}\mathbf{K}_{\mathrm{c}} \\
\mathbf{K}_{\mathrm{m}} \\
\mathbf{K}_{\mathbf{x}}\end{array}$ & $\begin{array}{l}0.00322 \\
0.00477 \\
0.0255\end{array}$ & $\begin{array}{l}0.508-3 \\
0.679-3 \\
0.406-2\end{array}$ & $\begin{array}{l}0.0232 \\
0.0343 \\
0.1834\end{array}$ & $\begin{array}{l}0.366-2 \\
0.535-2 \\
0.263-1\end{array}$ & $\begin{array}{l}0.116 \\
0.172 \\
0.917\end{array}$ & $\begin{array}{l}0.065-1 \\
0.235-1 \\
0.962-1\end{array}$ & $\begin{array}{l}0.555 \\
0.822 \\
4.39\end{array}$ & $\begin{array}{l}0.744-1 \\
0.915-1 \\
0.642\end{array}$ & $\begin{array}{c}1.968 \\
2.91 \\
15.55\end{array}$ & $\begin{array}{l}0.294 \\
0.464 \\
1.192\end{array}$ \\
\hline 6.493 & 0.17672 & $\begin{array}{l}\mathbf{K}_{\mathrm{c}} \\
\mathbf{K}_{\mathrm{m}} \\
\mathbf{K}_{\mathbf{x}}\end{array}$ & & & & & & & & & & \\
\hline 7.353 & 0.18443 & $\begin{array}{l}\mathbf{K}_{\mathbf{c}} \\
\mathbf{K}_{\mathbf{m}} \\
\mathbf{K}_{\mathbf{x}}\end{array}$ & $\begin{array}{l}0.00390 \\
0.00582 \\
0.0302\end{array}$ & $\begin{array}{l}0.591-3 \\
0.765-3 \\
0.480-2\end{array}$ & $\begin{array}{l}0.0223 \\
0.0333 \\
0.1725\end{array}$ & $\begin{array}{l}0.349-2 \\
0.522-2 \\
0.237-1\end{array}$ & $\begin{array}{l}0.0889 \\
0.1326 \\
0.688\end{array}$ & $\begin{array}{l}0.949-2 \\
0.123-1 \\
0.838-1\end{array}$ & $\begin{array}{l}0.272 \\
0.406 \\
2.10\end{array}$ & $\begin{array}{l}0.435-1 \\
0.609-1 \\
0.323\end{array}$ & $\begin{array}{l}0.574 \\
0.856 \\
4.44\end{array}$ & $\begin{array}{l}0.759-1 \\
0.932-1 \\
0.647\end{array}$ \\
\hline 11.527 & 0.21409 & $\begin{array}{l}\mathbf{K}_{\mathbf{c}} \\
\mathbf{K}_{\mathbf{m}} \\
\mathbf{K}_{\mathbf{x}}\end{array}$ & & & & & & & & & & \\
\hline 12.184 & 0.21794 & $\begin{array}{l}\mathbf{K}_{\mathrm{c}} \\
\mathbf{K}_{\mathrm{m}} \\
\mathbf{K}_{\mathbf{x}}\end{array}$ & $\begin{array}{l}0.00390 \\
0.00588 \\
0.0290\end{array}$ & $\begin{array}{l}0.591-3 \\
0.769-3 \\
0.463-2\end{array}$ & $\begin{array}{l}0.0215 \\
0.0324 \\
0.1600\end{array}$ & $\begin{array}{l}0.332-2 \\
0.511-2 \\
0.204-1\end{array}$ & $\begin{array}{l}0.0635 \\
0.0957 \\
0.473\end{array}$ & $\begin{array}{l}0.803-2 \\
0.981-2 \\
0.675-1\end{array}$ & $\begin{array}{l}0.1489 \\
0.225 \\
1.107\end{array}$ & $\begin{array}{l}0.173-1 \\
0.352-1 \\
0.044\end{array}$ & $\begin{array}{l}0.275 \\
0.415 \\
2.05\end{array}$ & $\begin{array}{l}0.439-1 \\
0.618-1 \\
0.311\end{array}$ \\
\hline 19.802 & 0.25379 & $\begin{array}{l}\mathbf{K}_{\mathrm{c}} \\
\mathbf{K}_{\mathrm{m}} \\
\mathbf{K}_{\mathbf{x}}\end{array}$ & $\begin{array}{l}0.00483 \\
0.00739 \\
0.0336\end{array}$ & $\begin{array}{l}0.684-3 \\
0.869-3 \\
0.526-2\end{array}$ & $\begin{array}{l}0.0180 \\
0.0276 \\
0.1251\end{array}$ & $\begin{array}{l}0.225-2 \\
0.441-2 \\
0.098-1\end{array}$ & $\begin{array}{l}0.0460 \\
0.0704 \\
0.320\end{array}$ & $\begin{array}{l}0.663-2 \\
0.848-2 \\
0.505-1\end{array}$ & $\begin{array}{l}0.0950 \\
0.1454 \\
0.661\end{array}$ & $\begin{array}{l}0.978-2 \\
0.162-1 \\
0.820-1\end{array}$ & $\begin{array}{l}0.140 \\
0.214 \\
0.974\end{array}$ & $\begin{array}{l}0.147-1 \\
0.331-1 \\
0.988-1\end{array}$ \\
\hline
\end{tabular}

$20.839 \quad 0.25779 \quad \mathrm{~K}_{\mathrm{c}}$

$\mathbf{K}_{\mathrm{m}}$

$\mathbf{K}_{\mathbf{x}}$

$28.517 \quad 0.28357 \quad \mathrm{~K}_{\mathrm{c}}$

$\mathbf{K}_{\mathrm{m}}$

$\begin{array}{lllllllllllllll}32.023 & 0.29371 & \mathrm{~K}_{\mathrm{c}} & 0.00503 & 0.702-3 & 0.0154 & 0.187-2 & 0.0349 & 0.542-2 & 0.0560 & 0.748-2 & 0.0724 & 0.860-2\end{array}$ $\begin{array}{lllllllllll}\mathrm{K}_{\mathrm{m}} & 0.00787 & 0.896-3 & 0.0241 & 0.382-2 & 0.0546 & 0.732-2 & 0.0876 & 0.943-2 & 0.1132 & 0.054-1\end{array}$ $\begin{array}{lllllllllll}\mathrm{K}_{\mathrm{x}} & 0.0308 & 0.489-2 & 0.0944 & 0.975-2 & 0.214 & 0.330-1 & 0.343 & 0.535-1 & 0.444 & 0.647-1\end{array}$

$34.958 \quad 0.30166 \quad \mathrm{~K}_{\mathrm{c}}$

$\mathbf{K}_{\mathrm{m}}$

$\mathbf{K}_{\mathbf{x}}$ 
Table V. (Continued) Partition coefficients between heptane and aqueous solutions of potassium-1-octylsulfonate

\begin{tabular}{|c|c|c|c|c|c|c|c|c|c|c|c|c|c|c|}
\hline \multirow[b]{2}{*}{$\mathbf{c}^{\prime}$} & \multirow[b]{2}{*}{$-\log \gamma$} & \multicolumn{3}{|c|}{ Octanol-(1) } & \multicolumn{2}{|c|}{ Decanol-(1) } & \multicolumn{2}{|c|}{ Dodecanol- (1) } & \multicolumn{2}{|c|}{$\begin{array}{l}\text { 1-Chloro- } \\
\text { octane }\end{array}$} & \multicolumn{2}{|c|}{$\begin{array}{c}\text { Octanol-(1) } \\
\text {-acetate }\end{array}$} & \multicolumn{2}{|c|}{$\begin{array}{c}\text { Nona- } \\
\text { none }(2)\end{array}$} \\
\hline & & & $\mathbf{K}$ & $\log K$ & K $\quad 1$ & $\log K$ & $\mathbf{K}$ & $\log \mathrm{K}$ & $\mathrm{K}$ & $\log \mathrm{K}$ & $\mathbf{K}$ & $\log K$ & $\mathbf{K}$ & $\log K$ \\
\hline 0.0000 & 0.00000 & $\begin{array}{l}\mathbf{K}_{\mathrm{c}} \\
\mathbf{K}_{\mathfrak{m}} \\
\mathbf{K}_{\mathbf{x}}\end{array}$ & $\begin{array}{r}147 \\
215 \\
1194\end{array}$ & $\begin{array}{l}2.167 \\
2.332 \\
3.077\end{array}$ & $\begin{array}{r}7880 \\
11500 \\
64000\end{array}$ & $\begin{array}{l}3.896 \\
4.061 \\
4.806\end{array}$ & & & & & & & & \\
\hline 0.0953 & 0.03009 & $\begin{array}{l}\mathbf{K}_{\mathrm{c}} \\
\mathbf{K}_{\mathrm{m}} \\
\mathbf{K}_{\mathbf{x}}\end{array}$ & & & & & & & & & & & & \\
\hline 0.4322 & 0.06011 & $\begin{array}{l}\mathbf{K}_{\mathrm{c}} \\
\mathbf{K}_{\mathrm{m}} \\
\mathbf{K}_{\mathbf{x}}\end{array}$ & & & & & & & & & & & & \\
\hline 1.1201 & 0.09042 & $\begin{array}{l}\mathbf{K}_{\mathrm{c}} \\
\mathbf{K}_{\mathrm{m}} \\
\mathbf{K}_{\mathbf{x}}\end{array}$ & $\begin{array}{r}(250) \\
(366) \\
(2020)\end{array}$ & $\begin{array}{l}(2.398) \\
(2.564) \\
(3.305)\end{array}$ & & & & & & & & & & \\
\hline 2.317 & 0.12106 & $\begin{array}{l}\mathbf{K}_{\mathrm{e}} \\
\mathbf{K}_{\mathrm{m}} \\
\mathbf{K}_{\mathbf{x}}\end{array}$ & & & & & & & & & & & & \\
\hline 3.199 & 0.13692 & $\begin{array}{l}\mathbf{K}_{\mathrm{c}} \\
\mathbf{K}_{\mathbf{m}} \\
\mathbf{K}_{\mathbf{x}}\end{array}$ & $\begin{array}{l}21.9 \\
32.3 \\
174\end{array}$ & $\begin{array}{l}1.340 \\
1.509 \\
2.241\end{array}$ & & & & & & & & & & \\
\hline 4.269 & 0.15231 & $\begin{array}{l}\mathbf{K}_{\mathrm{c}} \\
\mathbf{K}_{\mathrm{m}} \\
\mathbf{K}_{\mathbf{x}}\end{array}$ & $\begin{array}{r}7.45 \\
11.02 \\
58.90\end{array}$ & $\begin{array}{l}0.872 \\
1.042 \\
1.770\end{array}$ & $\begin{array}{l}23.3 \\
34.5 \\
184\end{array}$ & $\begin{array}{l}1.368 \\
1.538 \\
2.265\end{array}$ & $\begin{array}{r}28.0 \\
41.5 \\
221.0\end{array}$ & $\begin{array}{l}1.447 \\
1.618 \\
2.344\end{array}$ & & & & & & \\
\hline 6.493 & 0.17672 & $\begin{array}{l}\mathbf{K}_{\mathrm{c}} \\
\mathbf{K}_{\mathrm{m}} \\
\mathbf{K}_{\mathbf{x}}\end{array}$ & $\begin{array}{c}1.94 \\
2.89 \\
15.1\end{array}$ & $\begin{array}{l}0.287 \\
0.461 \\
1.179\end{array}$ & & & & & & & & & & \\
\hline 7.353 & 0.18443 & $\begin{array}{l}\mathbf{K}_{\mathbf{c}} \\
\mathbf{K}_{\mathrm{m}} \\
\mathbf{K}_{\mathbf{x}}\end{array}$ & & & $\begin{array}{c}2.91 \\
4.34 \\
22.5\end{array}$ & $\begin{array}{l}0.464 \\
0.638 \\
1.352\end{array}$ & $\begin{array}{c}4.20 \\
6.27 \\
32.5\end{array}$ & $\begin{array}{l}0.624 \\
0.797 \\
1.512\end{array}$ & $\begin{array}{r}57.5 \\
85.8 \\
445\end{array}$ & $\begin{array}{l}1.759 \\
1.934 \\
2.648\end{array}$ & & & $\begin{array}{r}65 \\
97 \\
503\end{array}$ & $\begin{array}{l}1.815 \\
1.987 \\
2.701\end{array}$ \\
\hline 11.527 & 0.21409 & $\begin{array}{l}\mathbf{K}_{\mathrm{c}} \\
\mathbf{K}_{\mathrm{m}} \\
\mathbf{K}_{\mathbf{x}}\end{array}$ & $\begin{array}{l}0.620 \\
0.934 \\
4.64\end{array}$ & $\begin{array}{l}0.792-1 \\
0.970-1 \\
0.667\end{array}$ & & & & & & & & & & \\
\hline 12.184 & 0.21794 & $\begin{array}{l}\mathbf{K}_{\mathrm{c}} \\
\mathbf{K}_{\mathrm{m}} \\
\mathbf{K}_{\mathbf{x}}\end{array}$ & & & $\begin{array}{l}0.909 \\
1.371 \\
6.77\end{array}$ & $\begin{array}{l}0.958-1 \\
0.137 \\
0.831\end{array}$ & $\begin{array}{r}1.35 \\
2.04 \\
10.05\end{array}$ & $\begin{array}{l}0.130 \\
0.310 \\
1.002\end{array}$ & $\begin{array}{l}34.5 \\
52.0 \\
257\end{array}$ & $\begin{array}{l}1.538 \\
1.716 \\
2.410\end{array}$ & $\begin{array}{l}34.3 \\
51.7 \\
255\end{array}$ & $\begin{array}{l}1.536 \\
1.714 \\
2.407\end{array}$ & $\begin{array}{c}24.0 \\
36.2 \\
179\end{array}$ & $\begin{array}{l}1.381 \\
1.559 \\
2.252\end{array}$ \\
\hline 19.802 & 0.25379 & $\begin{array}{l}\mathbf{K}_{\mathrm{c}} \\
\mathbf{K}_{\mathrm{m}} \\
\mathbf{K}_{\mathbf{x}}\end{array}$ & & & $\begin{array}{l}0.381 \\
0.583 \\
2.65\end{array}$ & $\begin{array}{l}0.581-1 \\
0.766-1 \\
0.423\end{array}$ & $\begin{array}{l}0.507 \\
0.776 \\
3.53\end{array}$ & $\begin{array}{l}0.705-1 \\
0.890-1 \\
0.547\end{array}$ & $\begin{array}{l}19.6 \\
30.0 \\
136\end{array}$ & $\begin{array}{l}1.292 \\
1.477 \\
2.134\end{array}$ & $\begin{array}{c}20.4 \\
31.2 \\
142\end{array}$ & $\begin{array}{l}1.310 \\
1.494 \\
2.152\end{array}$ & $\begin{array}{c}9.92 \\
15.2 \\
69.0\end{array}$ & $\begin{array}{l}0.997 \\
1.181 \\
1.839\end{array}$ \\
\hline 20.839 & 0.25779 & $\begin{array}{l}\mathbf{K}_{\mathrm{c}} \\
\mathbf{K}_{\mathrm{rm}} \\
\mathbf{K}_{\mathrm{x}}\end{array}$ & $\begin{array}{l}0.219 \\
0.336 \\
1.508\end{array}$ & $\begin{array}{l}0.340-1 \\
0.526-1 \\
0.179\end{array}$ & & & & & & & & & & \\
\hline 28.517 & 0.28357 & $\begin{array}{l}\mathbf{K}_{\mathrm{c}} \\
\mathbf{K}_{\mathrm{m}} \\
\mathbf{K}_{\mathbf{x}}\end{array}$ & $\begin{array}{l}0.151 \\
0.235 \\
0.962\end{array}$ & $\begin{array}{l}0.179-1 \\
0.371-1 \\
0.983-1\end{array}$ & & & & & & & & & & \\
\hline 32.023 & 0.29371 & $\begin{array}{l}\mathbf{K}_{\mathrm{c}} \\
\mathbf{K}_{\mathrm{m}} \\
\mathbf{K}_{\mathbf{x}}\end{array}$ & & & $\begin{array}{l}0.170 \\
0.266 \\
1.041\end{array}$ & $\begin{array}{l}0.231-1 \\
0.425-1 \\
0.018\end{array}$ & $\begin{array}{l}0.206 \\
0.322 \\
1.262\end{array}$ & $\begin{array}{l}0.314-1 \\
0.508-1 \\
0.101\end{array}$ & $\begin{array}{l}13.5 \\
21.1 \\
82.8\end{array}$ & $\begin{array}{l}1.130 \\
1.324 \\
1.918\end{array}$ & $\begin{array}{c}6.04 \\
9.44 \\
37.0\end{array}$ & $\begin{array}{l}0.781 \\
0.975 \\
1.568\end{array}$ & $\begin{array}{c}3.83 \\
6.00 \\
23.5\end{array}$ & $\begin{array}{l}0.583 \\
0.778 \\
1.371\end{array}$ \\
\hline 34.958 & 0.30166 & $\begin{array}{l}\mathbf{K}_{\mathbf{c}} \\
\mathbf{K}_{\mathbf{m}} \\
\mathbf{K}_{\mathbf{x}}\end{array}$ & $\begin{array}{l}0.111 \\
0.175 \\
0.658\end{array}$ & $\begin{array}{l}0.047-1 \\
0.243-1 \\
0.818-1\end{array}$ & & & & & & & & & & \\
\hline
\end{tabular}


Table VI. Partition coefficients between heptane and aqueous solutions of trimethyl-1-octylammoniumbromide

\begin{tabular}{|c|c|c|c|c|c|c|c|c|c|c|c|c|}
\hline \multirow[b]{2}{*}{$\mathbf{c}^{\prime}$} & \multirow[b]{2}{*}{$-\log \gamma$} & & \multicolumn{2}{|c|}{ Ethanol } & \multicolumn{2}{|c|}{ Propanol-(1) } & \multicolumn{2}{|c|}{ Butanol-(1) } & \multicolumn{2}{|c|}{ Pentanol-(1) } & \multicolumn{2}{|c|}{ Hexanol-(1) } \\
\hline & & & $\mathbf{K}$ & $\log K$ & K & $\log \mathrm{K}$ & $\mathbf{K}$ & $\log K$ & $\mathbf{K}$ & $\log K$ & $\mathbf{K}$ & $\log \mathrm{K}$ \\
\hline 0.0000 & 0.00000 & $\begin{array}{l}\mathbf{K}_{\mathbf{c}} \\
\mathbf{K}_{\mathbf{m}} \\
\mathbf{K}_{\mathbf{x}}\end{array}$ & $\begin{array}{l}0.00773 \\
0.0113 \\
0.0628\end{array}$ & $\begin{array}{l}0.888-3 \\
0.053-2 \\
0.798-2\end{array}$ & $\begin{array}{l}0.0246 \\
0.0345 \\
0.200\end{array}$ & $\begin{array}{l}0.391-2 \\
0.538-2 \\
0.301-1\end{array}$ & $\begin{array}{l}0.127 \\
0.185 \\
1.032\end{array}$ & $\begin{array}{l}0.104-1 \\
0.268-1 \\
0.014\end{array}$ & $\begin{array}{c}1.242 \\
1.814 \\
10.09\end{array}$ & $\begin{array}{l}0.094 \\
0.259 \\
1.004\end{array}$ & $\begin{array}{r}6.12 \\
8.94 \\
49.7\end{array}$ & $\begin{array}{l}0.787 \\
0.951 \\
1.696\end{array}$ \\
\hline 0.1034 & 0.03009 & $\begin{array}{l}\mathbf{K}_{\mathrm{c}} \\
\mathbf{K}_{\mathrm{m}} \\
\mathbf{K}_{\mathbf{x}}\end{array}$ & $\begin{array}{l}0.00575 \\
0.00839 \\
0.04659\end{array}$ & $\begin{array}{l}0.760-3 \\
0.924-3 \\
0.669-2\end{array}$ & $\begin{array}{l}0.0241 \\
0.0351 \\
0.1953\end{array}$ & $\begin{array}{l}0.383-2 \\
0.545-2 \\
0.291-1\end{array}$ & $\begin{array}{l}0.129 \\
0.188 \\
1.045\end{array}$ & $\begin{array}{l}0.111-1 \\
0.274-1 \\
0.019\end{array}$ & $\begin{array}{l}1.150 \\
1.677 \\
9.319\end{array}$ & $\begin{array}{l}0.061 \\
0.225 \\
0.969\end{array}$ & $\begin{array}{r}5.91 \\
8.62 \\
47.89\end{array}$ & $\begin{array}{l}0.772 \\
0.936 \\
1.680\end{array}$ \\
\hline 0.4692 & 0.06014 & $\begin{array}{l}\mathbf{K}_{\mathbf{c}} \\
\mathbf{K}_{\mathbf{m}} \\
\mathbf{K}_{\mathbf{x}}\end{array}$ & $\begin{array}{l}0.00413 \\
0.00603 \\
0.03337\end{array}$ & $\begin{array}{l}0.616-3 \\
0.780-3 \\
0.523-2\end{array}$ & $\begin{array}{l}0.0259 \\
0.0378 \\
0.2092\end{array}$ & $\begin{array}{l}0.413-2 \\
0.577-2 \\
0.321-1\end{array}$ & $\begin{array}{l}0.123 \\
0.179 \\
0.994\end{array}$ & $\begin{array}{l}0.090-1 \\
0.254-1 \\
0.997-1\end{array}$ & $\begin{array}{r}1.246 \\
1.818 \\
10.067\end{array}$ & $\begin{array}{l}0.096 \\
0.260 \\
1.003\end{array}$ & $\begin{array}{r}6.13 \\
8.94 \\
49.52\end{array}$ & $\begin{array}{l}0.787 \\
0.951 \\
1.695\end{array}$ \\
\hline 1.2158 & 0.09047 & $\begin{array}{l}\mathbf{K}_{\mathrm{c}} \\
\mathbf{K}_{\mathrm{m}} \\
\mathbf{K}_{\mathbf{x}}\end{array}$ & $\begin{array}{l}0.00391 \\
0.00571 \\
0.03139\end{array}$ & $\begin{array}{l}0.592-3 \\
0.757-3 \\
0.497-2\end{array}$ & $\begin{array}{l}0.0259 \\
0.9378 \\
0.2080\end{array}$ & $\begin{array}{l}0.413-2 \\
0.577-2 \\
0.318-1\end{array}$ & $\begin{array}{l}0.129 \\
0.188 \\
1.036\end{array}$ & $\begin{array}{l}0.111-1 \\
0.274-1 \\
0.015\end{array}$ & $\begin{array}{c}1.246 \\
1.819 \\
10.00\end{array}$ & $\begin{array}{l}0.096 \\
0.260 \\
1.000\end{array}$ & $\begin{array}{r}7.48 \\
10.92 \\
60.06\end{array}$ & $\begin{array}{l}0.874 \\
1.038 \\
1.779\end{array}$ \\
\hline 2.515 & 0.12116 & $\begin{array}{l}\mathbf{K}_{\mathrm{c}} \\
\mathbf{K}_{\mathbf{m}} \\
\mathbf{K}_{\mathbf{x}}\end{array}$ & $\begin{array}{l}0.00391 \\
0.00572 \\
0.03105\end{array}$ & $\begin{array}{l}0.592-3 \\
0.757-3 \\
0.492-2\end{array}$ & $\begin{array}{l}0.0250 \\
0.0366 \\
0.1986\end{array}$ & $\begin{array}{l}0.398-2 \\
0.563-2 \\
0.298-1\end{array}$ & $\begin{array}{l}0.123 \\
0.180 \\
0.977\end{array}$ & $\begin{array}{l}0.090-1 \\
0.255-1 \\
0.990-1\end{array}$ & $\begin{array}{l}1.101 \\
1.610 \\
8.744\end{array}$ & $\begin{array}{l}0.042 \\
0.027 \\
0.942\end{array}$ & $\begin{array}{r}7.21 \\
10.54 \\
57.26\end{array}$ & $\begin{array}{l}0.858 \\
1.023 \\
1.758\end{array}$ \\
\hline 3.501 & 0.13749 & $\begin{array}{l}\mathbf{K}_{\mathrm{c}} \\
\mathbf{K}_{\mathbf{m}} \\
\mathbf{K}_{\mathbf{x}}\end{array}$ & & & & & & & & & & \\
\hline 4.634 & 0.15251 & $\begin{array}{l}\mathbf{K}_{c} \\
\mathbf{K}_{\mathrm{m}} \\
\mathbf{K}_{\mathbf{x}}\end{array}$ & $\begin{array}{l}0.00413 \\
0.00605 \\
0.03222\end{array}$ & $\begin{array}{l}0.616-3 \\
0.782-3 \\
0.508-2\end{array}$ & $\begin{array}{l}0.0241 \\
0.0353 \\
0.1880\end{array}$ & $\begin{array}{l}0.382-2 \\
0.548-2 \\
0.274-1\end{array}$ & $\begin{array}{l}0.159 \\
0.233 \\
1.240\end{array}$ & $\begin{array}{l}0.201-1 \\
0.367-1 \\
0.093\end{array}$ & $\begin{array}{l}1.074 \\
1.574 \\
8.378\end{array}$ & $\begin{array}{l}0.031 \\
0.197 \\
0.923\end{array}$ & $\begin{array}{r}6.95 \\
10.19 \\
54.21\end{array}$ & $\begin{array}{l}0.842 \\
1.008 \\
1.734\end{array}$ \\
\hline 6.801 & 0.17487 & $\begin{array}{l}\mathbf{K}_{\mathrm{c}} \\
\mathbf{K}_{\mathrm{m}} \\
\mathbf{K}_{\mathbf{x}}\end{array}$ & & & & & & & & & & \\
\hline 7.981 & 0.18482 & $\begin{array}{l}\mathbf{K}_{r} \\
\mathbf{K}_{\mathrm{m}} \\
\mathbf{K}_{\mathbf{x}}\end{array}$ & $\begin{array}{l}0.00391 \\
0.00575 \\
0.02961\end{array}$ & $\begin{array}{l}0.592-3 \\
0.760-3 \\
0.471-2\end{array}$ & $\begin{array}{l}0.0241 \\
0.0354 \\
0.1825\end{array}$ & $\begin{array}{l}0.382-2 \\
0.549-2 \\
0.261-1\end{array}$ & $\begin{array}{l}0.1045 \\
0.1537 \\
0.7915\end{array}$ & $\begin{array}{l}0.019-1 \\
0.187-1 \\
0.898-1\end{array}$ & $\begin{array}{l}0.572 \\
0.841 \\
4.332\end{array}$ & $\begin{array}{l}0.757-1 \\
0.925-1 \\
0.637\end{array}$ & $\begin{array}{r}1.83 \\
2.69 \\
13.86\end{array}$ & $\begin{array}{l}0.262 \\
0.430 \\
1.142\end{array}$ \\
\hline 12.404 & 0.21416 & $\begin{array}{l}\mathbf{K}_{\mathrm{c}} \\
\mathbf{K}_{\mathrm{m}} \\
\mathbf{K}_{\mathbf{x}}\end{array}$ & & & & & & & & & & \\
\hline 13.225 & 0.21868 & $\begin{array}{l}\mathbf{K}_{\mathbf{c}} \\
\mathbf{K}_{\mathrm{n}} \\
\mathbf{K}_{\mathbf{x}}\end{array}$ & $\begin{array}{l}0.00391 \\
0.00578 \\
0.02821\end{array}$ & $\begin{array}{l}0.592-3 \\
0.762-3 \\
0.450-2\end{array}$ & $\begin{array}{l}0.0215 \\
0.0318 \\
0.1551\end{array}$ & $\begin{array}{l}0.332-2 \\
0.502-2 \\
0.190-1\end{array}$ & $\begin{array}{l}0.0782 \\
0.1156 \\
0.5643\end{array}$ & $\begin{array}{l}0.893-2 \\
0.063-1 \\
0.751-1\end{array}$ & $\begin{array}{l}0.250 \\
0.370 \\
1.804\end{array}$ & $\begin{array}{l}0.398-1 \\
0.568-1 \\
0.256\end{array}$ & $\begin{array}{l}0.502 \\
0.742 \\
3.622\end{array}$ & $\begin{array}{l}0.701-1 \\
0.870-1 \\
0.559\end{array}$ \\
\hline 21.493 & 0.25512 & $\begin{array}{l}\mathbf{K}_{\mathrm{c}} \\
\mathbf{K}_{\mathrm{n} 2} \\
\mathbf{K}_{\mathrm{x}}\end{array}$ & $\begin{array}{l}0.00460 \\
0.00686 \\
0.03055\end{array}$ & $\begin{array}{l}0.663-2 \\
0.836-3 \\
0.485-2\end{array}$ & $\begin{array}{l}0.0189 \\
0.0282 \\
0.1255\end{array}$ & $\begin{array}{l}0.276-2 \\
0.450-2 \\
0.098-1\end{array}$ & $\begin{array}{l}0.0574 \\
0.0856 \\
0.3812\end{array}$ & $\begin{array}{l}0.759-2 \\
0.932-2 \\
0.581-1\end{array}$ & $\begin{array}{l}0.138 \\
0.206 \\
0.916\end{array}$ & $\begin{array}{l}0.140-1 \\
0.314-1 \\
0.962-1\end{array}$ & $\begin{array}{l}0.213 \\
0.318 \\
1.415\end{array}$ & $\begin{array}{l}0.328-1 \\
0.502-1 \\
0.151\end{array}$ \\
\hline
\end{tabular}

$22.200 \quad 0.25771 \quad \mathrm{~K}_{\mathrm{c}}$

$\mathrm{K}_{\mathrm{m}}$

$\begin{array}{lll}30.192 & 0.28350 & \mathrm{~K}_{\mathrm{c}}\end{array}$

$\mathbf{K}_{\mathrm{m}}$

$\begin{array}{llllllll}\mathrm{K}_{\mathrm{c}} & 0.00483 & 0.684-3 & 0.0171 & 0.233-2 & 0.0475 & 0.677-2\end{array}$

$\begin{array}{llllllll}\mathrm{K}_{\mathrm{ml}} & 0.00731 & 0.864-3 & 0.0259 & 0.413-2 & 0.0719 & 0.857-2 \\ \mathrm{~K}_{\mathrm{x}} & 0.02752 & 0.440-2 & 0.0974 & 0.989-2 & 0.2707 & 0.432-1\end{array}$

$\begin{array}{llll}0.0834 & 0.921-2 & 0.115 & 0.059-1\end{array}$

$\begin{array}{lllll}0.1262 & 0.101-1 & 0.174 & 0.241-1\end{array}$

$\begin{array}{llll}0.4752 & 0.677-1 & 0.655 & 0.816-1\end{array}$

$\begin{array}{lll}36.799 & 0.30153 & \mathrm{~K}_{\mathrm{c}}\end{array}$

$\mathbf{K}_{\mathbf{c}}$
$\mathbf{K}_{\mathbf{m}}$
$\mathbf{K}_{\mathbf{x}}$ 
Table VI. (Continued) Partition coefficients between heptane and aqueous solutions of trimethyl-1-octylammoniumbromide

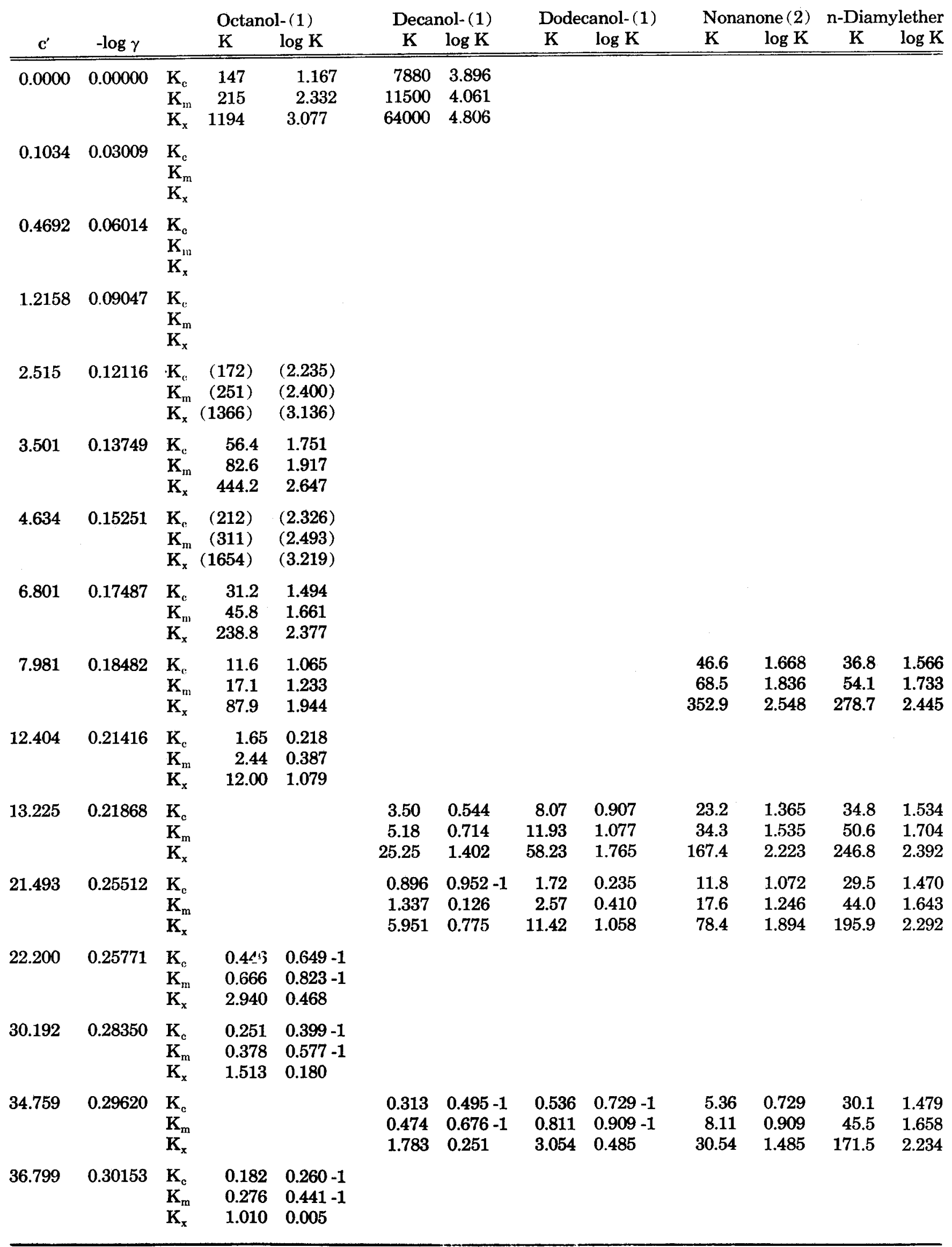


stance concentrations in the case of octanol-(1).

Variance analysis of the results have shown that within experimental error, there is no significant change in $\log \mathrm{K}$ especially for concentrations not higher than $0.2 \mathrm{~m}$. Therefore, for all other experiments, the concentration $0.2 \mathrm{~m}$. was chosen as high enough for analysis but low enough to be ideally diluted (see also Table IVa).

\section{Apparatus}

Construction and function (see Figure 1 and 2): The eluent is filled into a glass container (1) of internal diameter $20 \mathrm{~cm}$ and capacity 5 1. This container is connected through a three-way tap (3) which can be turned in two positions, either allowing the eluent to flow into the line and the burette (2), or (position in Figure 2) connecting only the burette with the line. This second position allows the sampleloading: the burette is emptied by pumping away the eluent and then the substance, diluted with the eluent, is filled into the burette. After loading, the tap is turned to the first position (connecting burette, container, and line).
The eluent passes through a sintered metal filter (4) and to a solution metering pump (5) (Beckman Model 746, 0-20 $\mathrm{ml} / \mathrm{min}$ ) which determines the velocity of the eluent with a precision of about $2 \%$. After the pump is an excess pressure valve giving a back pressure of about $1 / 2 \mathrm{~atm}$. At $\mathrm{N}$ a slow nitrogen stream $(\sim 2-3 \mathrm{ml} / \mathrm{min})$ is pressed into the eluent which then enters the separation tube (7). The tubes can be rotated with the aid of an electric motor (9) with a speed of up to 140 RPM. The separation tubes are connected by small bore stainless steel tubes 3 $\mathrm{mm}$ i.d. The whole apparatus is inclined to an extent that both the separation tubes and the connection tubes are descending for the movement of the eluent. After passing through all the tubes, the eluent is led to an overflow (10) where the main stream is collected (12). A bypass from the overflow goes to the detector (11) where the refraction index is measured continuously (Waters liquid chromatography, Model R 4) and is registered on a recorder.

For the description of the separation tubes see Figure 1 and the explanation in part one.
The apparatus can, of course, also be used with a smaller number of separation tubes.

Filling the separation tubes with the two phases: The tube is first placed in a horizontal position and filled completely with a solution of the hydrotropically active salt (or other solvent). By inclining the tube to a given angle, which of course must be higher than the position of the tube in the apparatus, a fraction of the stationary phase flows out. The tube is now placed into the apparatus and filled with the mobile phase without rotating in order to avoid foaming of the solution. After all the tubes are filled with the eluent, they can be rotated and the separation can be started.

\section{Acknowledgment}

This work was financially supported by Firmenich \& Cie., Geneva, Switzerland. We gratefully acknowledge the help in the experimental part of Heinz Fischer, Roland Ott, and Alderich Tresch.

\section{Literature Cited}

1. Rath, H., Rau, J., and Wagner, D., Melliand Textilber. 43, 718 (1962).

2. Michaelis, W., Schindler, 0 ., and Signer, R., Helv. Chim. Acta 48, 42 (1965).

3. Arn, H., Grob, E. C., and Signer, R., Helv. Chim. Acta 48, 851 (1965).

4. Signer, R., Allemann, K., Koehli, E., Lehmann, $W$., Meyer, $H$. , and Ritschard, W., Dechema Monograph. 27, 32 (1956).

5. Signer, R., and Arn, H., Helv. Chim. Acta (in press).

6. Neuberg, C., Biochem. Z. 76, 107 (1916).

7. Rath, H., Rau, J., and Wagner, D., Melliand Textilber. 44, 969 (1963).

8. Kovats, E. sz., Z. Anal. Chem. 181, 351 (1961). See also Kovats, E. sz., Advances of Chromatography, Vol. 1, J. C. Giddings and R. A. Keller, editors, M. Dekker, Inc., New York, 1965, p. 229.

9. Kovats, E. sz., and Weiss, P. B., Ber. Bunsenges. Physik. Chem. 69, 812 (1965).

10. Backer, H. J., Rec. Trav. Chim. 48, 949 (1929).

Manuscript received January 25, 1967 